\title{
Identification and Quantification of Calcium-Binding Proteins in Squid Axoplasm
}

\author{
Marie H. Krinks, ${ }^{1}$ Claude B. Klee, ${ }^{1}$ Harish C. Pant, ${ }^{2,3}$ and Harold Gainer ${ }^{2,3}$ \\ 'Laboratory of Biochemistry, National Cancer Institute, 2Laboratory of Neurochemistry, National Institute of Neurological \\ and Communicative Disorders and Stroke, National Institutes of Health, Bethesda, Maryland 20982, and ${ }^{3}$ Marine Biological \\ Laboratory, Woods Hole, Massachusetts 02540
}

\begin{abstract}
The identities and quantities of calcium-binding proteins were determined in axoplasm isolated from the squid giant axon. ${ }^{45} \mathrm{Ca}$-binding assays on nitrocellulose filters containing axoplasm proteins separated by SDS-polyacrylamide electrophoresis revealed 4 major calcium-binding bands. These included the high-molecular-weight $\left(M_{r}>330\right.$ and $220 \times$ $\left.10^{3}\right)$ neurofilament proteins, an unidentified protein band that migrated around $M_{r} 55,000$, and a diverse group of proteins that migrated together around $M_{r} 17,000$. The low-molecularweight $\left(M_{r}, 17,000\right)$ calcium-binding proteins could be resolved into calmodulin (ca. $120 \mu \mathrm{mol} / \mathrm{kg}$ axoplasm), 2 other $M_{r} 17,000$ calcium-binding proteins, and a small amount of calcineurin B. It is estimated that these calcium-binding proteins in squid axoplasm could theoretically bind about 1 mmol $\mathrm{Ca}^{2+} / \mathrm{kg}$ axoplasm. ${ }^{125}$-Calmodulin overlay and Western blot analyses disclosed a number of calmodulin-binding proteins in axoplasm. These included fodrin, calcineurin A, and $\mathrm{Ca}^{2+} / \mathrm{CaM}$ protein kinase II subunits.
\end{abstract}

Calcium ions are generally recognized as being involved in a wide variety of biochemical and physiological processes in cells (Rubin, 1974; Rasmussen, 1981; Evered and Whelan, 1986). These physiological actions of calcium usually occur when intracellular (cytosolic) free calcium rises from its resting level of around $0.1 \mu \mathrm{M}$ to between 0.2 and $1.2 \mu \mathrm{M}$ rarely, if ever, rising to over $10 \mu \mathrm{M}$ (Rasmussen, 1981). Higher intracellular concentrations are known to be deleterious to cell structure and function, e.g., in axons excessive calcium is well known to induce degeneration, in part, by activation of an intracellular calciumdependent neutral protease (Schlaepfer, 1974; Eagles et al., 1988). Hence, intracellular calcium is tightly regulated, often in a highly localized fashion within the cell (Rose and Loewenstein, 1975; Harary and Brown, 1984; Sawyer et al., 1985; Williams et al., 1985; Conner, 1986; Wier et al., 1987). While the mechanisms underlying these transient and localized increases in intracellular calcium that occur either by release from localized intracellular storage sites or by the opening of a diverse set of $\mathrm{Ca}^{2+}$ channels (McCleskey et al., 1986; Miller, 1987) have received considerable attention, much less is understood about the mechanisms that buffer and regulate intracellular calcium.

\footnotetext{
Received June 22, 1987; revised Oct. 20, 1987; accepted Oct. 20, 1987.

This paper is dedicated to the late Professor Peter F. Baker, who originally suggested that our laboratories collaborate on this research problem.

Correspondence should be addressed to Dr. Harold Gainer, NIH, Building 36 Room 40-20, Bethesda, MD 20892.

Copyright (C) 1988 Society for Neuroscience $0270-6474 / 88 / 062172-11 \$ 02.00 / 0$
}

What has been known for some time is that while intracellular free calcium is maintained at about $0.1 \mu \mathrm{M}$, the total intracellular calcium can range from 0.1 to $1.0 \mathrm{~mm}$, i.e., greater than $99.9 \%$ of the intracellular calcium is in a "bound" or "sequestered" form. The homeostasis of intracellular calcium has been attributed in various systems and circumstances to membrane transport mechanisms (DiPolo and Beauge, 1983), to milochondria and other specialized intracellular organelles (Blaustein et al., 1980; Henkart, 1980; Somlyo et al., 1985), and to buffering by intracellular calcium-binding proteins (Kretsinger, 1976; Martinosi, 1983; McBurney and Neering, 1987). Probably the most systematic and quantitative study of intracellular calcium buffering, to date, has been on the squid giant axon (Brinley, 1978; Baker and DiPolo, 1984; Baker, 1986). The total calcium content of squid axoplasm is between 50 and $200 \mathrm{mmol} / \mathrm{kg}$, whereas total magnesium in axoplasm is between 5 and $10 \mathrm{mmol} / \mathrm{kg}$. Free calcium ion in axoplasm is maintained at a concentration of $0.03-0.1 \mu \mathrm{M}$, while free $\mathrm{Mg}^{2+}$ is reported to be about $3 \mathrm{~mm}$ (Baker and DiPolo, 1984). Most of the $\mathrm{Mg}^{2+}$ binding can be accounted for by ATP and other cytoplasmic anions (Baker and DiPolo, 1984), whereas the $\mathrm{Ca}^{2+}$ binding is considerably more extensive and intricate. Baker and Schlaepfer $(1975,1978)$ found that the mechanisms of $\mathrm{Ca}^{2}$ । binding in squid axons and axoplasm could be divided into energy-dependent and energy-independent components. The energy-dependent mechanisms in axoplasm (e.g., mitochondria and endoplasmic reticulum) can be poisoned by various agents [e.g., cyanide, azide, trifluoromethoxyphenyl hydrazone (FCCP), ruthenium red], thereby revealing the energy-independent component. Under these conditions of metabolic poisoning, appreciable calcium-buffering capacity is retained by the axoplasm (Brinley, 1978; Baker and DiPolo, 1984; Baker, 1986). Brinley (1978) estimated that several hundred micromolar calcium can be buffered by the energyindependent component in axoplasm and that, under physiological levels of stimulation, this component alone could be adequate to buffer the resultant increase in intracellular calcium.

The above commentary points to the physiological relevance of the energy-independent calcium buffers in axoplasm, and raises questions as to their nature. Brinley (1978) and Baker and DiPolo (1984) have suggested that calcium-binding proteins could play such a role. Alema et al. (1973) isolated an unidentified $\mathrm{Ca}^{2+}$-binding protein in axoplasm with a low affinity for $\mathrm{Ca}^{2+}$ $\left(K_{\mathrm{a}}\right.$ of $\left.25-50 \mu \mathrm{M}\right)$ and a capacity for $\mathrm{Ca}^{2+}$ of $360 \mu \mathrm{mol} / \mathrm{kg}$, which could be related to the low-affinity buffering component reported by Baker and Schlaepfer $(1975,1978)$. In a preliminary report, Head and Kaminer (1980) found that squid axoplasm also contained the ubiquitous calcium-binding protein, calmodulin. In 
this paper, we have examined the identities of several calciumbinding proteins in squid axoplasm, have obtained quantitative estimates for some of them, and conclude that these molecules are sufficiently abundant in axoplasm to account for the $\mathrm{Ca}^{2+}$. buffering activity of the energy-independent system in axoplasm.

\section{Materials and Methods}

Materials. Bovine brain calmodulin-binding proteins and bovine brain calcineurin were obtained using calmodulin-Sepharose affinity chromatography as described by Klee et al. (1983). Rabbit skeletal muscle troponin $C$ was a gift of Paul Leavis (Boston Biomedical Research Institution, Boston, MA), and carp parvalbumin was kindly provided by Jacques Haiech (Centre de Recherches de Biochimie Macromoleculaire, Montpellier, France). Polyclonal antibodies against bovine brain calcium-binding proteins and calcineurin were raised in rabbits by conventional immunization procedures, and IgG fractions were obtained from preimmune and immune sera by 3 successive $0-40 \%\left(\mathrm{NH}_{4}\right)_{2} \mathrm{SO}_{4}$ precipitations. ${ }^{45} \mathrm{Ca}(4-50 \mathrm{Ci} / \mathrm{gm})$ was obtained from New England $\mathrm{Nu}-$ clear (Boston, MA). Bovine testis calmodulin was iodinated by the lactoperoxidase-glucose oxidase method to $1.4 \mathrm{~mol}$ iodine $/ \mathrm{mol}$ calmodulin (sp act, $10^{\mathrm{s}} \mathrm{dpm} / \mathrm{pmol}$ ), as described by Klee et al. (1983). Type IIIR E. coli alklaine phosphatase was obtained from Sigma (St. I ouis, MO)

Dissection of squid giant axon and extrusion of axoplasm. Giant axons were dissected from live squid (Loligo pealei) obtained at the Marine Biological Laboratory, Woods Holc, MA, as previously described (Pant et al., 1986). The giant axons were completely cleaned of all surrounding small fibers in artificial seawater, and subsequently rinsed in ice-cold isosmolar sucrose to remove the external seawater and blotted. The intact axons were either directly homogenized (together with their surrounding plasma membrane and sheath cells) or used to extrude axoplasm in the conventional manner (Lasek, 1974) into homogenizing buffer. The homogenizing buffer (for intact axons and extruded axoplasm) contained $5 \mathrm{~mm}$ EDTA, $1 \mathrm{mg} / \mathrm{ml}$ leupeptin, $40 \mathrm{~mm}$ Tris, pH 7.0. After homogenization of the tissue samples they were frozen at $-20^{\circ} \mathrm{C}$ until used.

Dephosphorylation of squid axoplasm proteins. Extruded squid axoplasm in homogenizing buffer was extensively dialyzed against dephosphorylation buffer $(50 \mathrm{~mm}$ Tris, $100 \mathrm{~mm} \mathrm{NaCl}, 1 \mathrm{~mm} \mathrm{ZnSO}, \mathrm{pH}$ 8.0) containing $1 \mathrm{~mm}$ phenylmethylsulfonyl fluoride (PMSF) (Sigma), and $0.1 \mathrm{mg} / \mathrm{ml}$ each of lcupeptin, pcpstatin $\mathrm{A}$, antipain, and bestatin (Peninsula Labs) to inhibit proteolysis. Two hundred micrograms of $E$. coli alkaline phosphatase (type IIIR; Sigma) were incubated together with $200 \mu \mathrm{g}$ axoplasm protein for $5 \mathrm{hr}$ at $37^{\circ} \mathrm{C}$. The incubation was terminated by precipitation in ice-cold $10 \%$ trichloroacetic acid (TCA). Control axoplasm samples were mixed with TCA before the addition of equal amounts of alkaline phosphatase. The TCA precipitates were washed in acetone $(2 \times)$, air-dried, and dissolved in SDS gel buffer for electrophoresis and Western blots as described below.

$S D S-P A G E$. Protein samples were dissolved in $0.05 \mathrm{~m} \mathrm{Tris-Cl}$ buffer $\mathrm{pH} 8.0$, containing $6 \mathrm{M}$ urea, $1 \%(\mathrm{wt} / \mathrm{vol}) \mathrm{SDS}, 0.5 \mathrm{~m}$ dithiothreitol (DTT), and either $5 \mathrm{~mm}$ EGTA or $5 \mathrm{mM} \mathrm{CaCl}$ (as indicated), and were boiled for $1 \mathrm{~min}$. These samples were then electrophoresed on 5-10\% polyacrylamide gradient gels using the buffer system of Laemmli (1970). The $M_{\mathrm{r}}$ marker proteins co-run on the gel wcre phosphorylase a $(97$ $\mathrm{KDa})$, bovine serum albumin $(68 \mathrm{KDa})$, catalase $(58 \mathrm{KDa})$, fumarase $(48 \mathrm{KDa})$, lactic dehydrogenase $(36 \mathrm{KDa})$, and beta-lactoglobulin $(17.5$ $\mathrm{KDa}$ ). After electrophoresis, the proteins on the gels were either stained by Coomassie brilliant blue or electrophoretically transferred to 0.45 $\mu \mathrm{m}$ nitrocellulose filters. A $0.2 \mu \mathrm{m}$ nitrocellulose filter was usually placed directly behind the $0.45 \mu \mathrm{m}$ filter to trap any proteins (e.g., CaM) that passed through the first filter. The electrophoretic transfer time was usually 20-24 hr and the current was $200 \mathrm{~mA}$, unless otherwise indicated. The transfer buffer was $25 \mathrm{~mm}$ Tris, $192 \mathrm{~mm}$ glycine, pH 8.3, made $20 \%(\mathrm{vol} / \mathrm{vol})$ with methanol.

Methods for detection and quantitation of calcium-binding proteins. The ${ }^{45} \mathrm{Ca}$ overlay method of Maruyama et al. (1984) was used to detect and quantitate calcium-binding proteins after separation by SDS-PAGE and transfer to nitrocellulose filtcrs. The concentration of calcium in the binding buffer did not exceed $10^{-6} \mathrm{M}$ in order to avoid significant dilution of ${ }^{45} \mathrm{Ca}$ added at a concentration of $5 \times 10^{-6} \mathrm{M}(1 \mu \mathrm{Ci} / \mathrm{ml})$. Appropriate amounts of calmodulin and calcineurin were run on the same gels to generate a calibration curve for each protein, since the amount of ${ }^{45} \mathrm{Ca}$ bound on the filter depends on the affinity of the protein for calcium, as well as on its rate of transfer to the nitrocellulose filters. In general, calcineurin B retains 20 times more calcium than calmodulin under these conditions. The radioactive bands, localized by autoradiography, were cut out and the radioactive calcium was eluted by soaking overnight in $0.5 \mathrm{ml}$ of $0.1 \mathrm{M}$ EGTA, $0.1 \mathrm{M} \mathrm{NaCl}$ at room temperature ( $85-95 \%$ of the counts werc cluted by this method). On the same gel (containing between 2 and $100 \mu \mathrm{g}$ of protein), the radioactivity is proportional to the amount of the protein applied to the gel, and the values varied from gel to gel by $\pm 15 \%$. Quantitative determinations were made only for proteins for which we had standards, i.e., calcineurin B and calmodulin.

Western blots were performed by the method of Towbin et al. (1979), and IgG complexes where detected on the nitrocellulose filter with biotinylated horseradish peroxidase and 3,3'-diaminobenzidine tetrahydrochloride as substrate, both obtained from Vector labs. Conditions of complete transfer were tested by transferring $1-3 \mu \mathrm{g}$ purified bovine calcineurin under the same conditions and testing for residual protein on the gel after transfer using Coomassie blue. For quantitation of calcineurin, the amount of cross-reacting protein was determined by densitometric analysis of the filters with a Laser Zcinch densitometer. For quantitation purposes, 5-50 ng of calcineurin were run on the same gel as the unknown protein to generate a linear standard curve.

${ }^{125}$ I-Calmodulin binding was performed by the overlay method (Glenney and Weber, 1980; Carlin et al., 1981), either directly on gels, as described by Klee et al. (1983), or after transfer to nitrocellulose (Hubbard and Klee, 1987). A standard curve with varying amounts of calcineurin was used for quantitation. Protein concentration was determined by the method of Lowry et al. (1951).

\section{Results}

\section{Detection of calcium-binding proteins in axoplasm}

Figure 1 illustrates the major calcium-binding proteins in the squid giant axon (lane 3) and extruded axoplasm (lane 4), as demonstrated by the ${ }^{45} \mathrm{Ca}^{2+}$ overlay method of Maruyama et al. (1984). The autoradiographs shown in lanes 3 and 4 show the binding of ${ }^{45} \mathrm{Ca}^{2+}\left(5 \times 10^{-6} \mathrm{M}\right)$, in the presence of $60 \mathrm{mM} \mathrm{KCl}$ and $5 \mathrm{mM} \mathrm{MgCl}_{2}$, to SDS-PAGE-separated proteins transferred to nitrocellulose filters. Protein patterns of gels that contained comparable tissue samples but were stained by Coomassie blue are shown in lanes 1 and 2 of Figure 1. Both protein-staining and ${ }^{45} \mathrm{Ca}^{2+}$-binding patterns are virtually identical for intact axon (Fig. 1, lanes 1 and 3) and axoplasm samples (lanes 2 and 4). This might have been expected, since axoplasm constitutes over $99 \%$ of the total protein in the $350-400$-diameter- $\mu \mathrm{m}$ cleaned giant axons used in this study. As can be seen in Figure 1 , there are 4 prominent bands of ${ }^{45} \mathrm{Ca}$ binding in axoplasm. These are labeled A-D and have $M_{\mathrm{r}}$ values of $>330,220,55$, and $17 \times 10^{3}$, respectively. Bands $\mathrm{A}$ and $\mathrm{B}$ comigrated with the 2 forms of high-molecular-weight neurofilament protein found in squid axoplasm, which are known to be highly phosphorylated (Pant et al., 1978, 1986), and band D comigrates, at this level of resolution, with a number of "E-F-hand" calcium-binding proteins (e.g., calmodulin).

Although the identities of the calcium-binding proteins found in Figure 1, band D are the main subject of this paper, we were intrigued to find that the neurofilament proteins could also bind ${ }^{45} \mathrm{Ca}^{2+} \mu \mathrm{M}$ in the presence of $5 \mathrm{mM} \mathrm{Mg}^{2+}$. Since, as pointed out above, these neurofilament proteins are highly phosphorylated, containing about $20 \mathrm{~mol}$ phosphate $/ \mathrm{mol}$ neurofilament protein (Eagles et al., 1988), we treated axoplasm samples with alkaline phosphatase in order to extensively dephosphorylate these proteins. The results of these experiments on the effect of dephosphorylation ${ }^{45} \mathrm{Ca}^{2+}$ binding are illustrated in Figure 2. Lanes 13 show protein staining on gels, and lanes 4-6 show $\mathrm{Ca}^{2+}$-binding patterns on nitrocellulose filters of comparable protein samples. Since the axoplasm samples in Figure 2 also contained 


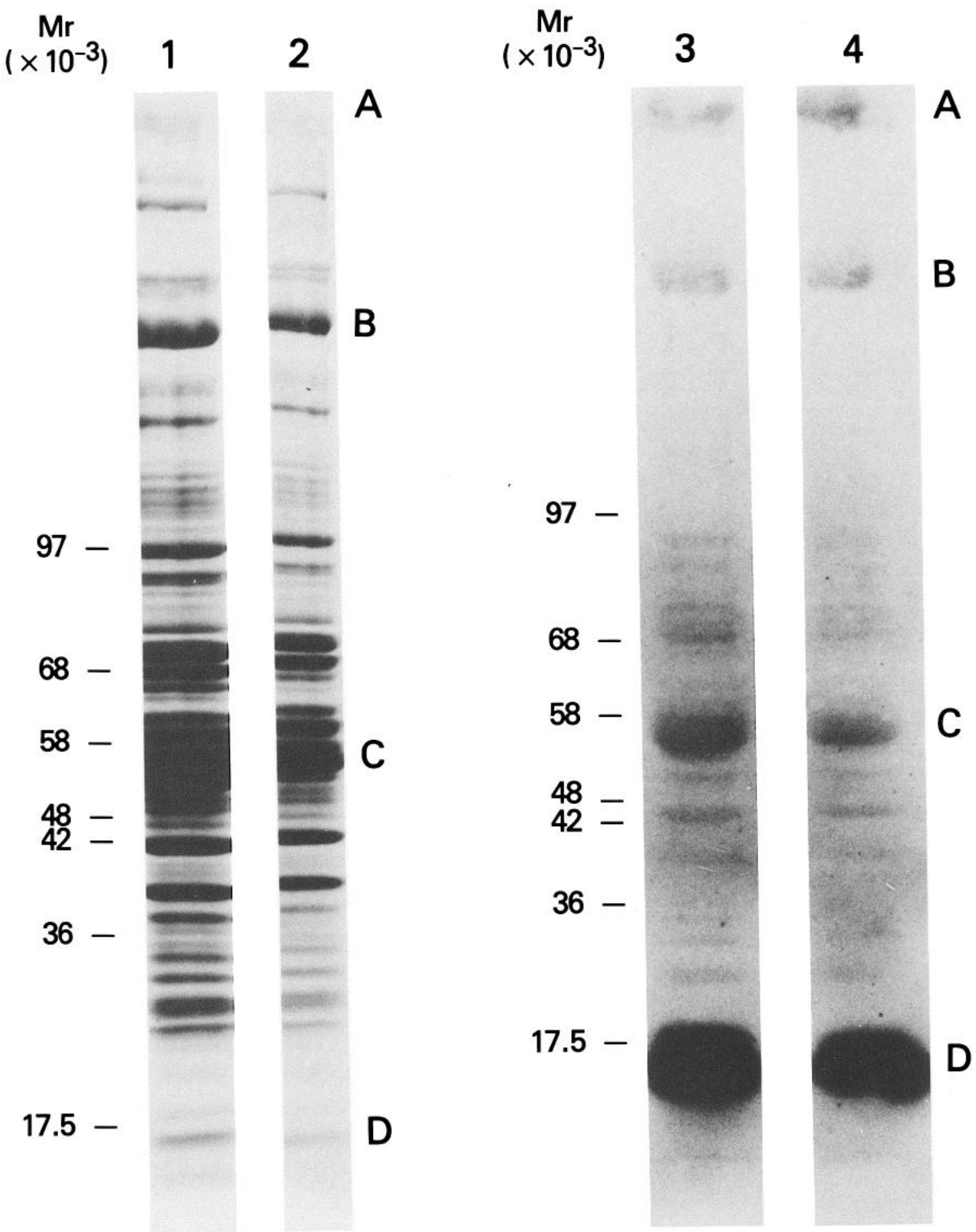

Figure 1. Calcium-binding proteins in squid axon and extruded axoplasm. Proteins from dissected squid giant axons ( $228 \mu \mathrm{g}$ protein, lanes 1 and 3 ) and extruded axoplasm ( $226 \mu \mathrm{g}$ proteins, lanes 2 and 4$)$ were separated by SDS-PAGE and tested for their ability to bind ${ }^{45} \mathrm{Ca}^{2+}$, as described in Materials and Methods. The autoradiogram of the $0.45 \mu \mathrm{m}$ nitrocellulose membrane is shown in lanes 3 and 4 , and the protein staining pattern is shown in lanes 1 and 2 . The major calcium-binding proteins in squid axoplasm are labeled $A\left(M_{\mathrm{r}}>330 \mathrm{~K}\right), B\left(M_{\mathrm{r}} 220 \mathrm{~K}\right), C\left(M_{\mathrm{r}} 54 \mathrm{~K}\right)$, and $D$ $\left(M_{\mathrm{r}} 17 \mathrm{~K}\right)$. Molecular-weight marker protein positions are shown for the gels and nitrocellulose filters on the left side of each pair.

exogenous alkaline phosphatase, the staining pattern (lane 1) and ${ }^{45} \mathrm{Ca}^{2+}$-binding pattern (lane 4 ) of the alkaline phosphatase alone are also shown in Figure 2. This enzyme ran as a broad single band and appeared to bind some ${ }^{45} \mathrm{Ca}^{2+}$, but its migration position did not obscure visualization of the major $\mathrm{Ca}^{2+}$-binding bands (A-D) in axoplasm. The dephosphorylated axoplasm (lane
3) showed a dramatic decrease in the apparent molecular weights of bands $\mathrm{A}$ and $\mathrm{B}$ in comparison to that of the control axoplasm (lane 2), but no significant change in the molecular weight of any other axoplasm protein. This fall in molecular weights of the high-molecular-weight neurofilament proteins as a result of dephosphorylation has been reported previously for mamma- 


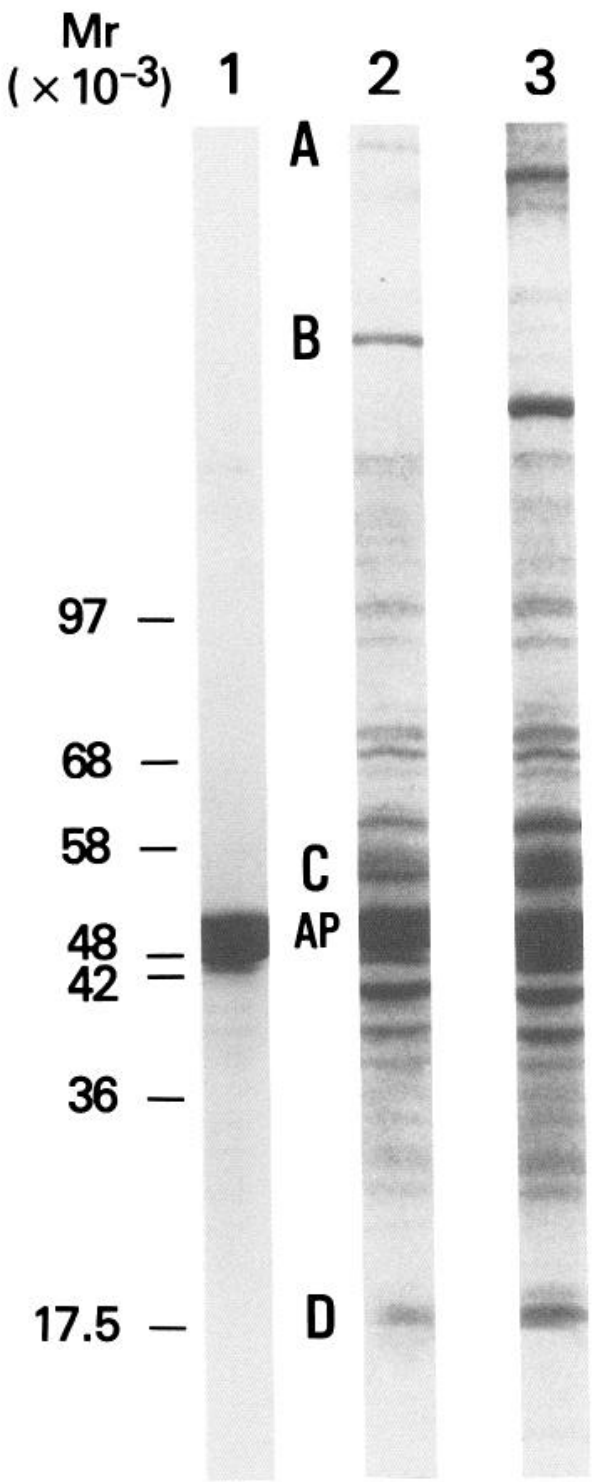

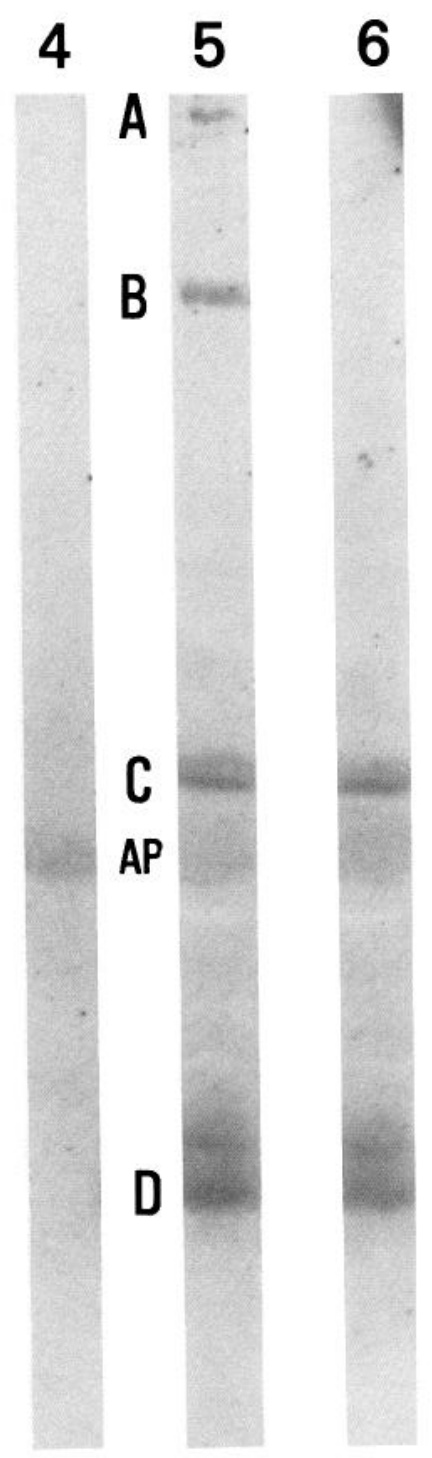

Figure 2. Calcium binding to alkaline phosphatase-treated axoplasm. Axoplasm extruded from the giant axon was separated by SDS-PAGE in the presence of $5 \mathrm{~mm}$ EGTA and was either stained for protein (lanes 2 and 3) or transferred for $21 \mathrm{hr}$ to a $0.2 \mu \mathrm{m}$ nitrocellulose membrane and exposed to ${ }^{45} \mathrm{Ca}^{2+}$ (lanes 5 and 6). Lanes 1 (protein stain) and $4\left({ }^{45} \mathrm{Ca}^{2+}\right.$ binding to nitrocellulose) contained $80 \mu \mathrm{g}$ alkaline phosphatase $(A P)$ only. Lanes 2 and 5 served as controls (AP added after TCA treatment) for the AP-treated axoplasm in lanes 3 and 6 . Note that the control lanes ( 2 and 5) resembled axoplasm data in Figure 1, whereas AP-treated axoplasm showed dramatic and selective $M_{\mathrm{t}}$ decreases in bands $A$ and $B$ (lane 3) and loss of ${ }^{45} \mathrm{Ca}^{2+}$ binding by these proteins (lane 6). lian (Carden et al., 1985) and squid (Cohen et al., 1987) neurofilament proteins. The effect of this dephosphorylation procedure was equally dramatic on ${ }^{45} \mathrm{Ca}^{2+}$ binding. While no apparent changes were seen in bands $\mathrm{C}$ and $\mathrm{D}$ as a result of dephosphorylation, the $\mathrm{Ca}^{2+}$-binding properties of bands $\mathrm{A}$ and B were completely eliminated by dephosphorylation (compare control lane 5 to dephosphorylated lane 6 in Fig. 2). Thus, we conclude that the calcium-binding properties of the high-molecular-weight neurofilament proteins in squid axoplasm are dependent on their phosphorylation state.

\section{Analysis of the low-molecular-weight calcium-binding proteins in axoplasm by the ${ }^{45} \mathrm{Ca}$-binding method}

The migration rates of the low-molecular-weight calcium-binding proteins in axoplasm (i.e., ca. $M_{\mathrm{r}} 17,000$ in Fig. 1) on SDS gels are compared to known "E-F-hand" calcium-binding proteins (Kretsinger, 1982) in Figure 3. Electrophoresis was performed for axoplasm proteins and $\mathrm{CaM}$ in the presence and absence of $\mathrm{Ca}^{2+}$, since some calcium-binding proteins (e.g., $\mathrm{CaM}$ ) have increased migration rates in the presence of $\mathrm{Ca}^{2+}$. In EGTA, band D in axoplasm (Fig. 3, lane II) was separated into $2{ }^{45} \mathrm{Ca}$ - binding bands, a minor band and a major band ( 1 and 2 in Fig. 3). Band 1 migrated somewhat above troponin C (TNC), and band 2 appeared to comigrate with CaM and overlapped only slightly with calcineurin $(\mathrm{Cn})$. Parvalbumin $(\mathrm{Pa})$ migrated more rapidly than any of the calcium-binding proteins in axoplasm. When electrophoresed in the presence of $\mathrm{Ca}^{2+}$ (Fig. 3, right), the axoplasm calcium-binding proteins were further resolved into 3 distinct ${ }^{45} \mathrm{Ca}$-binding protein bands, $1,2 \mathrm{a}$, and $2 \mathrm{~b}$. While the migration rate of band 1 was only slightly affected by $\mathrm{Ca}^{2+}$, band 2 was split into 2 bands, both of which, like CaM, migrated more rapidly in $\mathrm{Ca}^{2+}$. Band $2 \mathrm{a}$ continued to comigrate with bovine $\mathrm{CaM}$, whereas band $2 \mathrm{~b}$ migrated more rapidly. Thus, on the basis of the information in Figure 3, squid axoplasm does not contain $\mathrm{Pa}$ or TNC, but contains 3 distinct low- $M_{\mathrm{r}}$ calcium-binding proteins, one of which comigrates with bovine $\mathrm{CaM}$ under 2 conditions $\left( \pm \mathrm{Ca}^{2+}\right)$ of electrophoresis.

In Figure 4 , the low- $M_{\mathrm{r}}$ calcium-binding proteins were subjected to an additional treatment. In this experiment, the electrophoresed proteins were electrophoretically transferred for much longer times and at higher currents (i.e., $20 \mathrm{hr}$ at $200 \mathrm{~mA}$ ) to a $0.45 \mu \mathrm{m}$ nitrocellulose filter backed up by a $0.2 \mu \mathrm{m}$ nitrocellulose 


\section{EGTA}
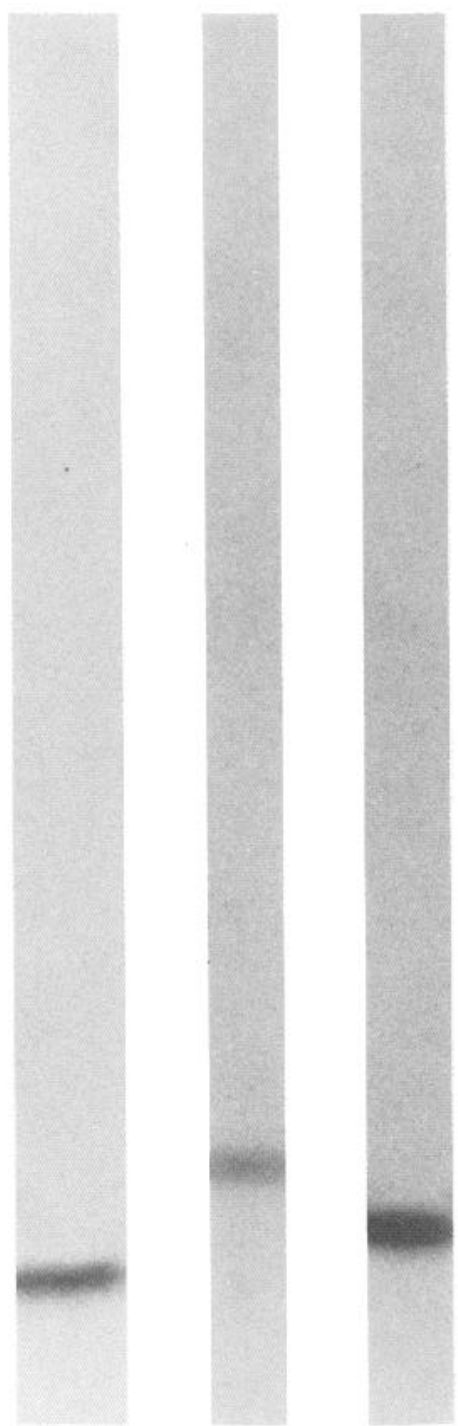

\section{$\mathrm{Pa}$}
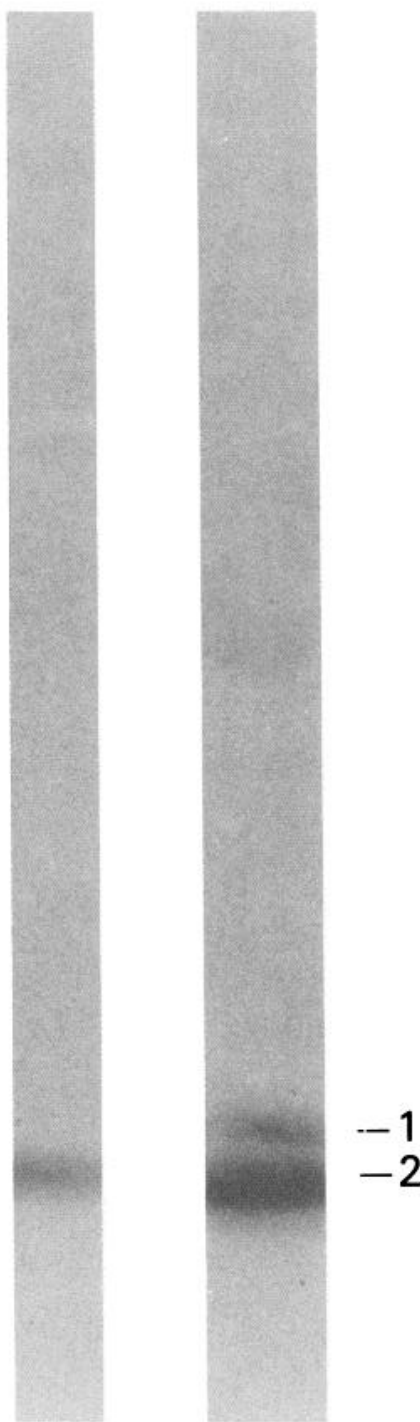

II
$\mathrm{Ca}^{2+}$

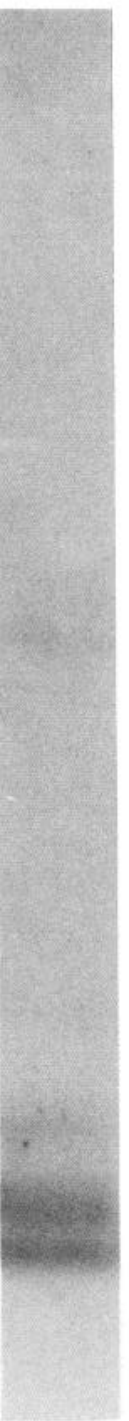

II

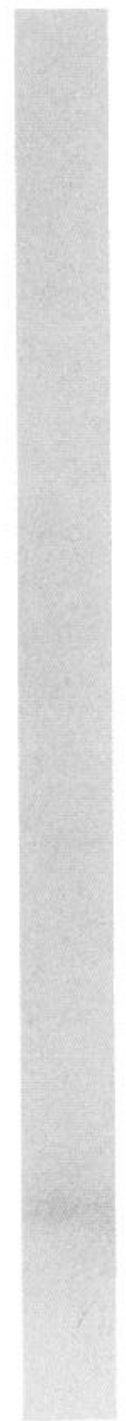

$\mathrm{CaM}$

Figure 3. Comparison of D group of squid axoplasm calcium-binding proteins (See Fig. 1) with known "E-F-hand" calcium-binding proteins. Various known calcium-binding proteins and axoplasm proteins (lane II) were subjected to SDS-PAGE and transfered to a $0.45 \mu \mathrm{m}$ nitrocellulose membrane (4 hr and $100 \mathrm{~m} \mathrm{~A})$ then tested for ${ }^{45} \mathrm{Ca}^{2+}$ binding, as described in Materials and Methods. The samples contained either 5 mM EGTA or $5 \mathrm{mM} \mathrm{CaCl}_{2}$ prior to electrophoresis, as indicated at the top. A short transfer time was used in this experiment to prevent loss of calmodulin $(\mathrm{CaM})$ or troponin $\mathrm{C}(\mathrm{TNC})$, which are not as well retained on the $0.45 \mu \mathrm{m}$ nitrocellulose as are calcineurin $\mathrm{B}(\mathrm{Cn})$ or parvalbumin $(\mathrm{Pa})$. The amounts of protein electrophored were $2 \mu \mathrm{g} \mathrm{Pa}, 2 \mu \mathrm{g} \mathrm{TNC}, 2 \mu \mathrm{g}$ Cn (as CnA and CnB), $2 \mu \mathrm{g} \mathrm{CaM}$, and $190 \mu \mathrm{g}$ axoplasm protein (lane II). The calcium-binding proteins in axoplasm are labeled $1,2,2 \mathrm{a}$, and $2 \mathrm{~b}$. The relatively lower intensity of labeling of CaM and TNC reflects the lower affinities of calcium of these 2 proteins as compared to Pa or CnB. The higher-molecular-weight bands are not seen here because of the short transfer time used, and although $\mathrm{C} n$ was electrophoresed in those experiments, only the $\mathrm{CnB}$ component is detected by the calcium-binding method.

filter (see Materials and Methods), and both filters were tested for ${ }^{45} \mathrm{Ca}$ binding. The $0.45 \mu \mathrm{m}$ filter is shown on the left, and the $0.2 \mu \mathrm{m}$ filter on the right of Figure 4 . Under these conditions, bovine CaM mainly passes through the $0.45 \mu \mathrm{m}$ filter and is primarily trapped on the $0.2 \mu \mathrm{m}$ filter, whereas bovine calcineurin $(\mathrm{CnB})$ is primarily trapped on the $0.45 \mu \mathrm{m}$ filter and considerably less on the $0.2 \mu \mathrm{m}$ filter (shown in lanes 1, Fig. 4). The axoplasm proteins A-C were virtually completely trapped by the $0.45 \mu \mathrm{m}$ filter (lanes II, Fig. 4). By use of this procedure, it was possible to reveal (in EGTA electrophoresis) that another minor ${ }^{45} \mathrm{Ca}^{2+}$-binding band was present, and that this band (band 3) comigrated with and partitioned between the filters like bovine $\mathrm{CnB}$. In both the EGTA and $\mathrm{Ca}^{2+}$, gel electrophoresis band 1 bound principally to the $0.45 \mu \mathrm{m}$ filter. Band 2 (in EGTA) and bands $2 \mathrm{a}$ and $2 \mathrm{~b}$ (in $\mathrm{Ca}^{2+}$ ) were partitioned almost equally between the 2 filters. In this regard, putative squid $\mathrm{CaM}$ (i.e., band 2a in Figs. 3 and 4) differed from the bovine CaM. The data in Figs. 3 and 4 allowed the tentative identification of band $2 \mathrm{a}$ as bovine-like $\mathrm{CaM}$, and of band 3 as bovine-like $\mathrm{CnB}$. We then determined the quantities of the bovine-like CaM (band 

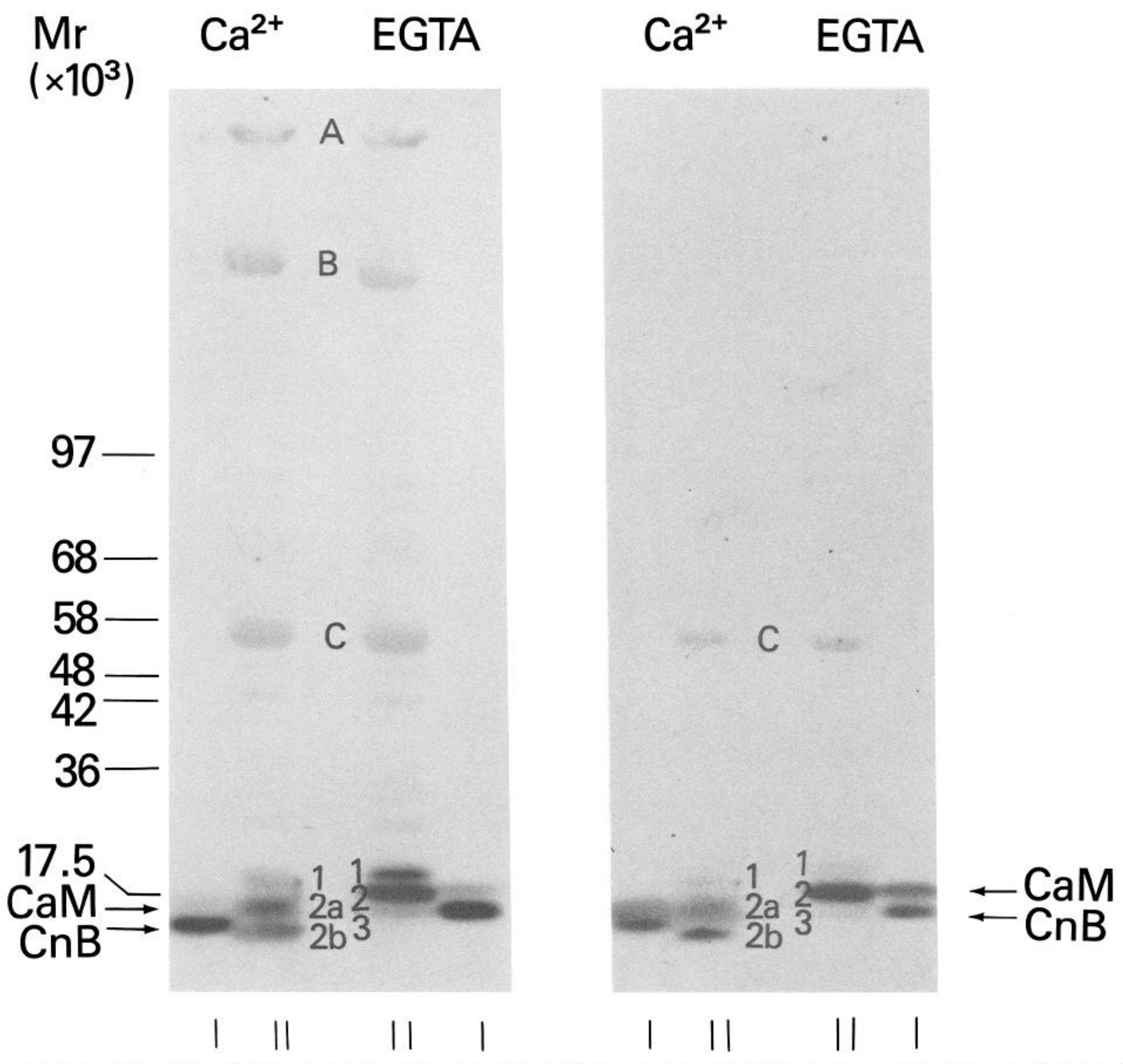

Figure 4. Binding of ${ }^{45} \mathrm{Ca}^{2+}$ to calmodulin, calcineurin, and squid axoplasm proteins under long transfer conditions with the use of $0.2 \mu \mathrm{m}$ nitrocellulose backup membrane. Mixtures of $3 \mu \mathrm{g} \mathrm{CaM}$ and $2 \mu \mathrm{g} \mathrm{Cn}$ (lane 1 ) or squid axoplasm proteins (190 $\mu \mathrm{g}$, lane $I I)$ containing either $5 \mathrm{~mm}$ EGTA or $5 \mathrm{mM} \mathrm{CaCl}_{2}$, as indicated, were subjected to SDS-PAGE. After electrophoresis, the proteins were transferred for $20 \mathrm{hr}$ at $200 \mathrm{~mA}$ to a $0.45 \mu \mathrm{m}$ nitrocellulose membrane with a $0.2 \mu \mathrm{m}$ nitrocellulose membrane directly behind it. Transfer conditions and calcium binding are described in Materials and Methods. Under these conditions, bovine CaM passes through the $0.45 \mu \mathrm{m}$ membrane and is better retained on the $0.2 \mu \mathrm{m}$ backup membrane (lane 1). The ${ }^{45} \mathrm{Ca}^{2+}$ binding is shown for the $0.45 \mu \mathrm{m}$ membrane (left side) and the $0.2 \mu \mathrm{m}$ membrane (right side). The positions of $M_{\mathrm{r}}$ marker proteins are shown on the left side, and the migration positions of $\mathrm{CaM}$ and $\mathrm{CnB}$ in the presence of $\mathrm{Ca}^{2+}$ and $\mathrm{EGTA}$ are shown on the left and right sides, respectively. Note that bands A, B, C, and some group D components $(1,2,2 \mathrm{a}, 2 \mathrm{~b})$ in axoplasm, are retained on the $0.45 \mu \mathrm{m}$ membrane (left), whereas bands $2,2 \mathrm{a}$, and $2 \mathrm{~b}$ also significantly pass to the backup $0.2 \mu \mathrm{m}$ membrane (right).

2a) and $\mathrm{CnB}$ (band 3) in axoplasm by comparing the ${ }^{45} \mathrm{Ca}$ binding to these bands using standard curves of ${ }^{45} \mathrm{Ca}$ binding to purified bovine brain $\mathrm{CaM}$ and $\mathrm{CnB}$ (see Materials and Methods). These data are shown in Table 1. On the basis of the ${ }^{45} \mathrm{Ca}^{2+}$-binding method, putative squid $\mathrm{CaM}$ and $\mathrm{CnB}$ constitute $2.5-3 \%$ and $0.3 \%$, respectively, of total proteins in axoplasm.

\section{Identification and quantitation of calcineurin in axoplasm by Western blot and ${ }^{125}$ I-calmodulin-binding methods}

Since the $\mathrm{CnB}$ subunit of calcineurin represents the calciumbinding component of this protein phosphatase, it was possible to detect it by the ${ }^{45} \mathrm{Ca}^{2+}$-binding method (Fig. 4). However, the other subunit of this molecule, $\mathrm{CnA}$, does not bind $\mathrm{Ca}^{2+}$ but binds calmodulin (Klee et al., 1983). Hence, we have used a Western blot method to identify and quantify $\mathrm{CnA}$ and $\mathrm{CnB}$ (Fig. 5), as a well as a ${ }^{125} \mathrm{I}-\mathrm{CaM}$ binding method to identify and quantify CnA. Figure 5 illustrates Western blots of purified bovine calcineurin (lanes 1 and 4) and squid axoplasm (lanes 2 and 3) immunostained with either control preimmune IgGs (lanes 1 and 2) or anti-bovine calcineurin IgGs (lanes 3 and 4). As can be seen (lane 4), the $\mathrm{CnA}$ and $\mathrm{CnB}$ are both stained by the anti-bovine calcineurin IgG. In axoplasm, 2 high-molecularweight proteins were detected by both the preimmune and anticalcineurin IgGs. These represented nonspecific staining due to biotin- or avidin-binding proteins in the axoplasm (M. Krinks, unpublished observations). However, 2 bands corresponding in 
Figure 5. Detection of calcineurin in axoplasm by Western blots using antibovine calcineurin IgG. SDS gel electrophoresis and transfer to a $0.45 \mu \mathrm{m}$ nitrocellulose membrane were as described in Materials and Methods. Lanes 1 and 4 contained $20 \mathrm{ng}$ calcineurin; lanes 2 and 3 contained $188 \mu \mathrm{g}$ axoplasm proteins. Lanes 1 and 2 were treated with control $\operatorname{IgG}(30 \mu \mathrm{g} / \mathrm{ml})$ and lanes 3 and 4 with anti-calcineurin $\mathrm{IgG}$ $(22 \mu \mathrm{g} / \mathrm{ml})$. The $M_{\mathrm{r}} \mathrm{s}$ of the marker proteins are shown on the left. The migration of bovine brain calcineurin $\mathrm{A}$ and $\mathrm{B}$ is indicated by arrows on the right.

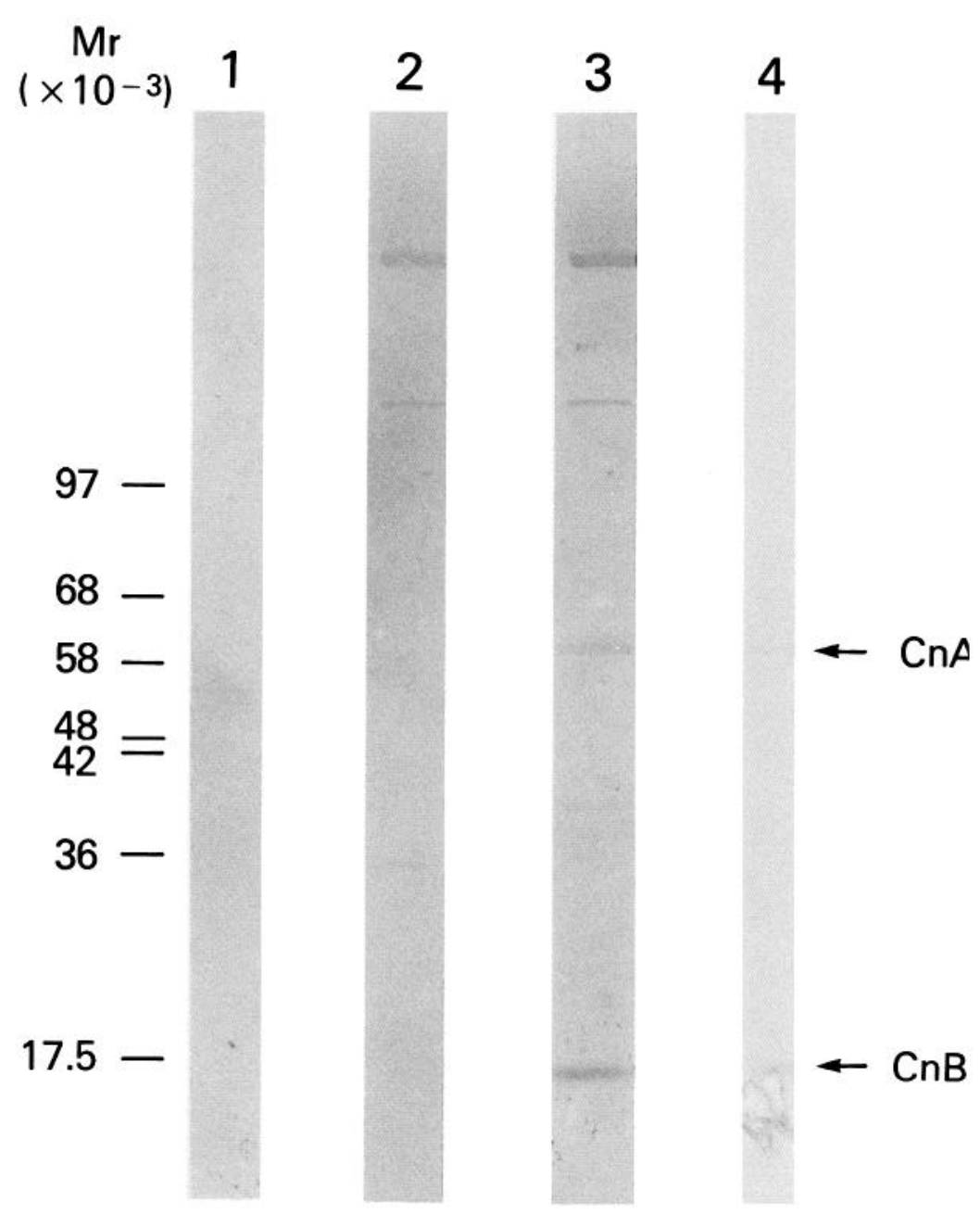

Table 1. Comparison of calmodulin and calcineurin in squid axoplasm and bovine brain ${ }^{a}$

\begin{tabular}{|c|c|c|c|}
\hline \multirow[b]{2}{*}{$\begin{array}{l}\text { Calcium-binding } \\
\text { protein }\end{array}$} & \multirow[b]{2}{*}{$\begin{array}{l}\text { Quantitative } \\
\text { method }^{b}\end{array}$} & \multicolumn{2}{|c|}{$\begin{array}{l}\text { Total protein } \\
(\mu \mathrm{g} / 100 \mu \mathrm{g})\end{array}$} \\
\hline & & $\begin{array}{l}\text { Squid } \\
\text { axoplasm }\end{array}$ & $\begin{array}{l}\text { Bovine } \\
\text { brain }^{c}\end{array}$ \\
\hline Calmodulin (CaM) & ${ }^{45} \mathrm{Ca}^{2+}$ binding & $2.5-3.0$ & $0.5-1.0$ \\
\hline \multirow[t]{2}{*}{ Calcineurin $\mathrm{A}(\mathrm{CnA})$} & ${ }^{125} \mathrm{I}$-CaM overlay & 0.05 & n.d. ${ }^{d}$ \\
\hline & Western blot & 0.06 & n.d. \\
\hline \multirow[t]{2}{*}{ Calcineurin $\mathrm{B}(\mathrm{CnB})$} & ${ }^{45} \mathrm{Ca}^{2+}$ binding & 0.3 & 0.3 \\
\hline & Western blot & 0.2 & 0.9 \\
\hline
\end{tabular}

${ }^{a}$ Axoplasm calcineurin (A and $\mathrm{B}$ subunits) and calmodulin in axoplasm, identified by their $M_{\mathrm{r}} \mathrm{s}$ after SDS gel electrophoresis, were quantitated as described in Materials and Methods by comparison with known amounts of the purified bovine brain proteins run in the same gels. The protein content is that of the native protein and, in the case of calcineurin, of the A-B complex $\left(M_{r} 80,000\right)$.

${ }^{b}$ Quantitative methods are described in Materials and Methods. Calcineurin B was run in the presence of EGTA and transferred for $24 \mathrm{hr}$. The numbers are the sums of the values obtained with the 0.45 and $0.2 \mu \mathrm{m}$ membranes (see Fig. 4). Calmodulin was quantitated either after a short transfer $(3 \mathrm{hr})$ to a $0.2 \mu \mathrm{m}$ filter, or a long transfer to 0.45 and $0.2 \mu \mathrm{m}$ filters, like calcineurin B. It was run in the presence of calcium to resolve the other calcium-binding proteins (e.g., see Fig. 4).

- Data for bovine brain were obtained by similar techniques (Klee and Vanaman, 1982; Manalan and Klee, 1984; M. H. Krinks, A. S. Manalan, and C. B. Klee, unpublished observations).

${ }^{d}$ Not determined. migration positions to $\mathrm{CnA}$ and $\mathrm{CnB}$ were detected with the anti-calcineurin IgG (lane 3), but not with the preimmune IgG (lane 2). Quantitation of the $\mathrm{CnA}$ and $\mathrm{CnB}$ by the Western blot method was performed (see Materials and Methods), and the data shown in Table 1. Calcineurin B was found to constitute $0.2 \%$ of total axoplasm protein (surprisingly close to the $0.3 \%$ value found using the ${ }^{45} \mathrm{Ca}^{2+}$-binding method, suggesting that the antibody's affinities for bovine and squid $\mathrm{CnB}$ were comparable), and calcineurin A relatively less, i.e., $0.06 \%$ of total axoplasm protein. Calcineurin B is relatively conserved, whereas $\mathrm{CnA}$ differs considerably between species (Iwasa and Ishiguro, 1986); therefore, a Western blot quantitation method using antibovine calcineurin $\mathrm{IgG}$ to quantitate squid $\mathrm{CnA}$ could conceivably give erroneous values. However, an independent quantitative assay using a ${ }^{125} \mathrm{I}-\mathrm{CaM}$-binding assay also showed that the $\mathrm{CnA}$ content in axoplasm was lower than that of $\mathrm{CnB}$ (see Table 1 and below).

Figure 6 illustrates the use of the ${ }^{125} \mathrm{I}$-calmodulin overlay method (see Materials and Methods) to identify $\mathrm{CnA}$ as well as other CaM-binding proteins in squid axoplasm. Lane 4 in Figure 6 shows ${ }^{125}$ I-calmodulin binding on nitrocellulose to which SDSPAGE-separated bovine calcineurin $(0.6 \mu \mathrm{g}$ purified calcineurin containing $\mathrm{CnA}$ and $\mathrm{CnB}$ in complex) had been transferred. Lane 3 shows, for comparison, a ${ }^{125}$ I-CaM overlay of proteins from bovine brain, which contains a substantial amount of $\mathrm{CnA}$ 


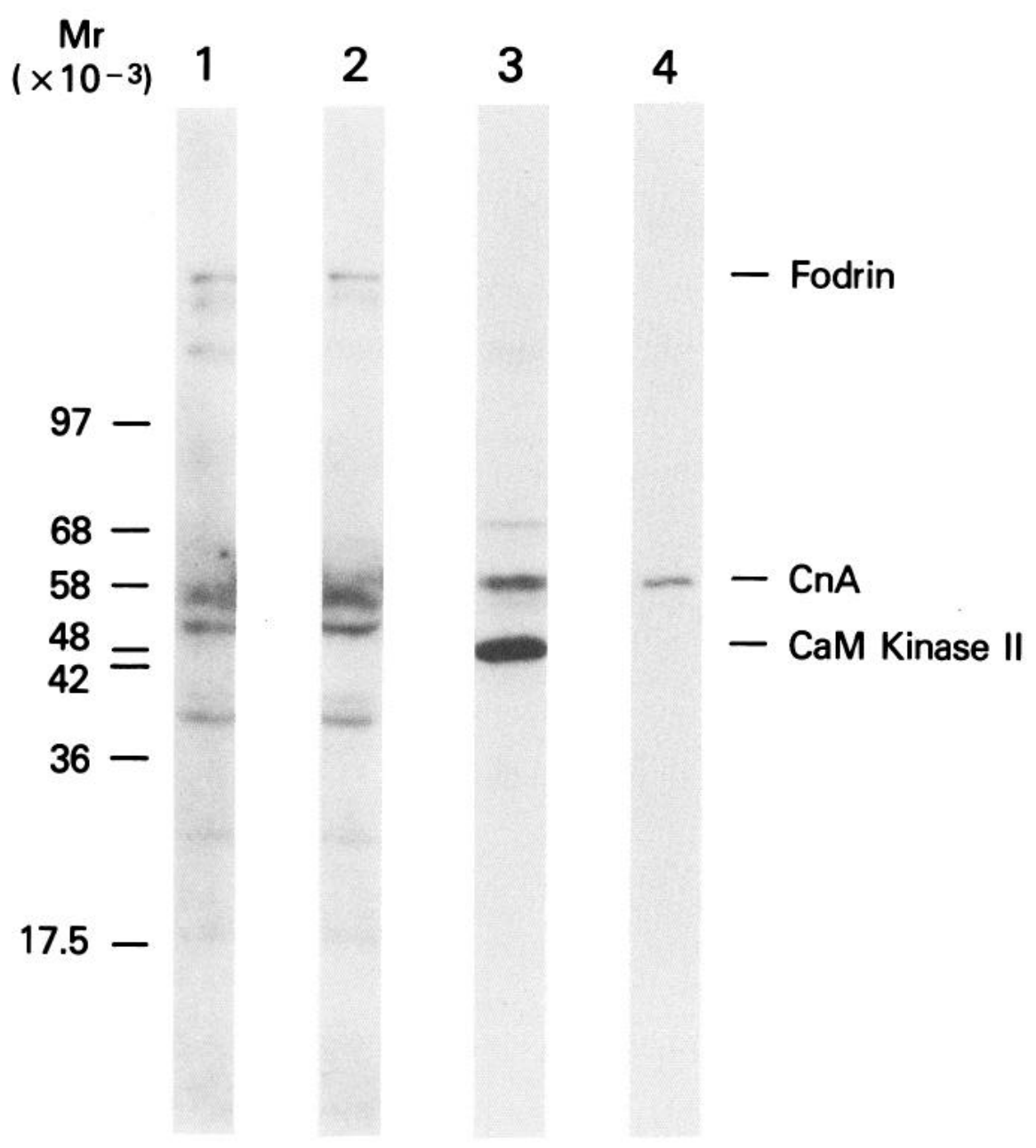

Figure 6. Detection of calmodulinbinding proteins in axoplasm by ${ }^{125} \mathrm{I}-$ calmodulin binding to proteins transferred to nitrocellulose membranes. SDS gel electrophoresis, protein transfer, and binding of ${ }^{125} \mathrm{I}$-calmodulin to the filters were performed as described in Materials and Methods and the autoradiograms are shown. Lane 1 , squid axon proteins $(152 \mu \mathrm{g})$; lane 2 , squid axoplasm protein $(110 \mu \mathrm{g})$; lane 3 , bovine brain homogenate (110 $\mu \mathrm{g})$; and lane 4 , calcineurin $(0.6 \mu \mathrm{g})$. The exposure times were $24 \mathrm{hr}$ (lanes 1, 2, and 4) and $3 \mathrm{hr}$ (lane 3). The migration of marker proteins is shown on the left, that of known brain calmodulin-binding proteins is indicated on the right. and $\mathrm{Ca}^{2+} / \mathrm{CaM}$ protein kinase II. Homogenates of intact squid axons and extruded axoplasm are shown in Figure 6, lanes 1 and 2, respectively. While many ${ }^{125} \mathrm{I}-\mathrm{CaM}$-binding proteins can be detected in axoplasm (Fig. 6, lane 2), only 4 of these are identifiable at the present time. These include the highest-molecular-weight band, which comigrates with fodrin, a heavily stained pair of bands between the $M_{\mathrm{r}} 48$ and 58 markers, which correspond to the $2 \mathrm{Ca}^{2+} / \mathrm{CaM}$ protein kinase II subunits (about 54 and $58 \mathrm{KDa}$ ) found in squid nervous system (Bass et al., 1987), and a minor band comigrating with CnA (about $61 \mathrm{KDa}$ ). The presence of fodrin in axoplasm was confirmed by Western blot assays using antibodies aginast bovine CaM-binding proteins (see Fig. 7), and also bovine fodrin-specific antibodies (not illustrated). Bovine brain fodrin is also detectable by the overlay method if longer autoradiographic exposures are used (data not shown), and both bovine brain and axoplasm contain a $M_{\mathrm{r}}$ 150,000 CaM-binding protein (Fig. 6). A quantitative estimate from the ${ }^{125} \mathrm{I}-\mathrm{CaM}$ binding assay of $\mathrm{CnA}$ (see Materials and Methods) gave a value of $0.05 \%$ of total axoplasm protein (Table 1), again close to the estimate of $0.06 \%$ obtained using the Western blot method (Table 1).

Figure 7 shows another Western blot assay, using antibodies against all bovine brain proteins that are retained by a CaMSepharose affinity column (see Materials and Methods). These antibodies detected a variety of CaM-binding proteins in West- ern blots of bovine brain protein (CMBP IgG lane 1, Fig. 7), most notably fodrin, a $M_{\mathrm{r}} 68,000$ protein, calcium-binding protein 18 (CBP18), and CnB. Staining of squid axoplasm proteins by this mixed antibody also reveals staining, albeit weak, of some corresponding bands, e.g., fodrin, which is weakly stained, and $\mathrm{CnB}$, which is strongly stained (Fig. 7, CMBP IgG lane 2). These immunochemical data, like those in Figure 5, suggest that some immunogenic epitopes in $\mathrm{CnB}$ are conserved between squid and bovine $\mathrm{CnB}$; however, this is obviously not the case for other CaM-binding proteins. Note also that some "CaMbinding proteins" identified by CaM affinity chromatography do not bind ${ }^{125} \mathrm{I}-\mathrm{CaM}$ on the nitrocellulose overlay assays, e.g., $\mathrm{CnB}$ and CPB18 (compare Figs. 6, 7). The reason is obvious for calcineurin, which is a complex of $\mathrm{CnA}$ and $\mathrm{CnB}$; $\mathrm{CnB}$ is "affinity purified" on the CaM-Sepharose column only because of its association with the $\mathrm{CnA}$ subunit during the chromatography, but is separated from CnA in SDS-PAGE. Thus, the ${ }^{125} \mathrm{I}-$ CaM overlay method is a more direct test of whether a protein subunit is a true CaM-binding protein.

In summary, there are a number of distinct calcium-binding proteins detectable in squid axoplasm (Figs. 1, 3, 4), of which only 2 are also found in abundance in bovine brain, i.e., $\mathrm{CaM}$ and $\mathrm{CnB}$. Because these 2 proteins appear to be highly conserved between animal species, the ${ }^{45} \mathrm{Ca}^{2+}$-binding method that was used to quantitatively compare these 2 proteins (Table 1) in 


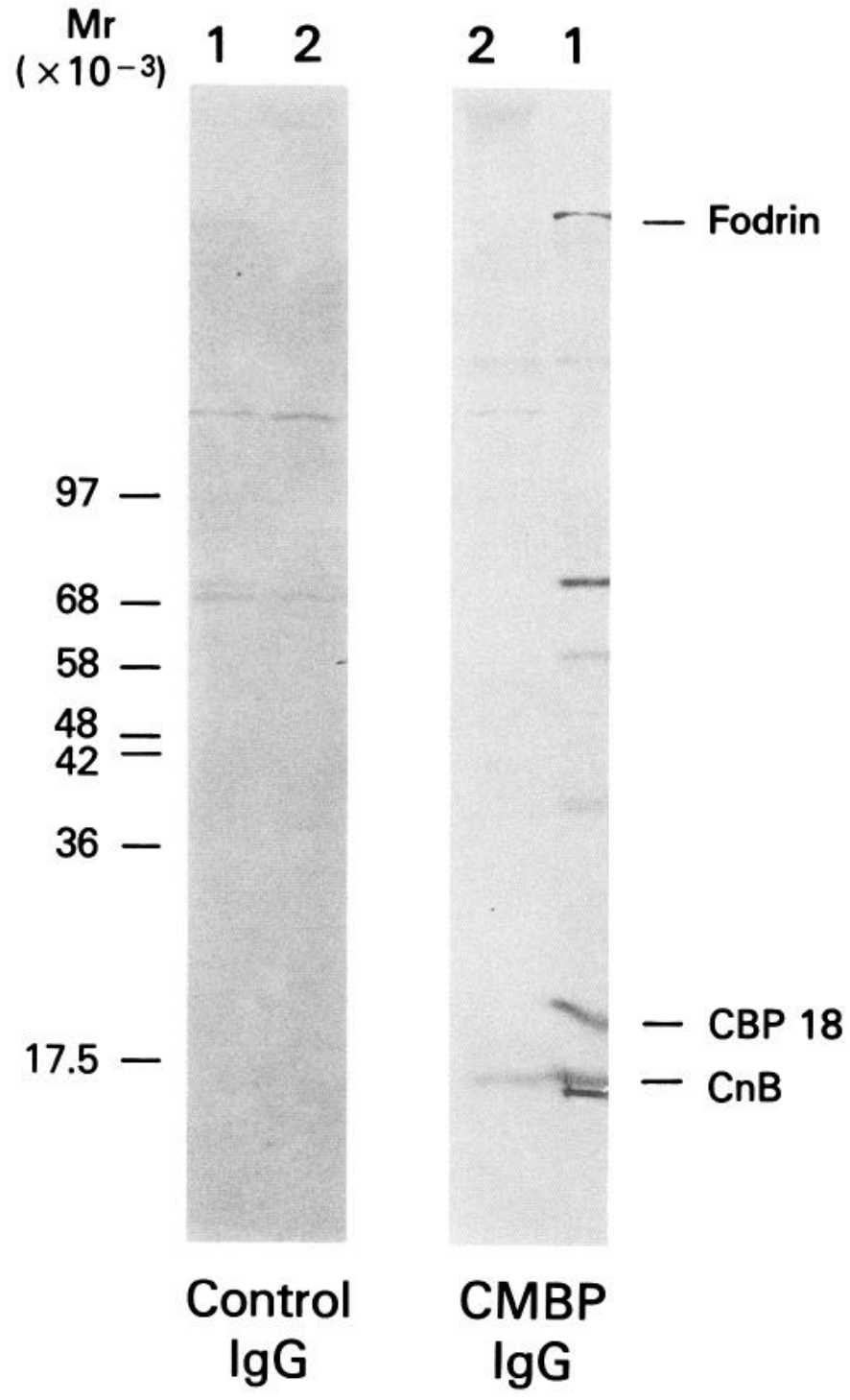

Figure 7. Detection of calmodulin-binding proteins in squid axoplasm with antibodies raised against bovine brain calmodulin-binding proteins. The conditions of the experiments were as described in legend to Figure 5. Left panel: lane 1, $440 \mu \mathrm{g}$ bovine brain proteins; lane 2, $94 \mu \mathrm{g}$ squid axoplasm proteins. Right panel: lane $1,55 \mu \mathrm{g}$ bovine brain proteins; lane 2, $94 \mu \mathrm{g}$ squid axoplasm proteins. The transferred proteins were treated with an $\mathrm{IgG}$ solution $(46 \mu \mathrm{g} / \mathrm{ml})$ prepared from the preimmune rabbit serum (left) or with IgG solution, $80 \mu \mathrm{g} / \mathrm{ml}$, from the serum from the rabbit immunized with bovine CAM-binding proteins (right). The doublet seen around $68,000 M_{\mathrm{r}}$ in axoplasm in the preimmune serum is due to an avidin- or biotin-binding protein and not to specific staining by the IgGs.

different species probably is based on more conservative assumptions (i.e., of comparable affinity for $\mathrm{Ca}^{2+}$ ) than the Western blot assay (where one might expect a wider variation of affinities for squid versus bovine proteins using antibody raised against the bovine subunits). Overall, it is interesting to note that squid axoplasm contains 2-3 times the amount of $\mathrm{CaM}$ than bovine brain homogenate, whereas the $\mathrm{CnB}$ estimate is equivalent for the 2 tissues. In addition to the bovine-like $\mathrm{CaM}$ (band 2a, Fig. 4), squid axoplasm also contains 2 distinct $M_{\text {r }}$ 17,000 calcium-binding proteins (bands 1 and 2b, Fig. 4) which we cannot quantitate by the ${ }^{45} \mathrm{Ca}^{2+}$-binding method since we have no purified standard. However, the intensities of ${ }^{45} \mathrm{Ca}^{2+}$. binding to bands 1 and $2 \mathrm{~b}$ are comparable to that of CaM (lanes
II in Fig. 4), and therefore they would appear to be comparable to that of $\mathrm{CaM}$ in contributing to the $\mathrm{Ca}^{2+}$-binding capacity of axoplasm (see Discussion).

\section{Discussion}

Our findings of a wide variety of calcium-binding (Figs. 1, 4) and calmodulin-binding (Fig. 6) proteins in squid axoplasm are, in themselves, not remarkable. We were, however, surprised to find that neurofilament proteins could selectively bind calcium (Figs. 1, 2), and that calmodulin was found in such a large quantity (Table 1). An analysis of these calcium-binding proteins (see below) leads us to conclude that these proteins can account completely for the energy-independent component of calcium buffering in axoplasm (Brinley, 1978; Baker and DiPolo, 1984; Baker, 1986).

Although we have no direct quantitative estimates for the calcium-binding capacities of the squid neurofilament proteins, a recent report by Abercrombie et al. (1986) on the $M_{\mathrm{r}} 150,000$ and 160,000 neurofilament proteins in Myxicola giant axons is particularly relevant. These authors found a calcium-binding capacity of $8.5 \mu \mathrm{mol} / \mathrm{gm}$ of neurofilament protein and an affinity of $0.4 \mu \mathrm{M} \mathrm{Ca}^{2+}$, corresponding to about $100 \mu \mathrm{mol} \mathrm{Ca}{ }^{2+} / \mathrm{kg}$ of Myxicola axoplasm. This indicates that each mole of neurofilament protein binds approximately $1.2 \mathrm{~mol}$ of calcium, considerably less than the approximately $20 \mathrm{~mol}$ of phosphate found per mole of high-molecular-weight neurofilament protein (Eagles et al., 1988). This difference between the phosphate content and calcium-binding capacity of neurofilament proteins makes it unlikely that the calcium is simply binding to the phosphates on this molecule; nevertheless, it is interesting that the calcium binding is completely eliminated by dephosphorylation of the protein (Fig. 2). In squid axoplasm, neurofilaments constitute about $13 \%$ of total protein (Morris and Lasek, 1984), and of this, about half (about $24 \mu \mathrm{mol} / \mathrm{kg}$ axoplasm) is in the phosphorylated high-molecular-weight form (Baumgold et al., 1981). If the squid neurofilament protein calcium-binding capacity is comparable to that found in Myxicola (Abercrombie et al., 1986), then the contribution of the squid neurofilament proteins to calcium buffering in axoplasm would be approximately $24 \mu \mathrm{mol} /$ $\mathrm{kg}$ axoplasm.

By far the greatest calcium-binding in squid axoplasm is associated with calmodulin (band 2a, Fig. 4) and other $M_{\mathrm{r}} 17,000$ calcium-binding proteins (bands 1 and 2b, Fig. 4). Head et al. (1983) isolated $2 M_{\mathrm{r}} 17,000$ calcium-binding proteins from squid optic lobe by phenothiazine-Sepharose affinity chromatography. One of these proteins corresponded to calmodulin, on the basis of amino acid analysis (e.g., it contained a trimethyllysine residue), its comigration on SDS gels wtih bovine calmodulin, and its ability to activate phosphodiesterase. The second protein did not comigrate with bovine calmodulin under some gel conditions, did not contain trimethyllysine, and did not significantly activate phosphodiesterase. Both of these proteins bound 3-4 mol of calcium ions/mol at $0.1 \mathrm{~mm}$ free $\mathrm{Ca}^{2+}$; both bound chlorpromazine in $\mathrm{a} \mathrm{Ca}^{2+}$-dependent manner, and these proteins were present in comparable amounts in squid optic lobe. Two $M_{\mathrm{r}}$ 17,000 calcium-binding proteins that we found in squid axoplasm appear to be similar to the proteins described above for the optic lobe. In Figure 4, band 2a comigrates in gel electrophoresis like bovine CaM, whereas band $2 \mathrm{~b}$ does not, and probably corresponds to the unique squid calcium-binding protein described by Head et al. (1983). Because of the intensities of their ${ }^{45} \mathrm{Ca}^{2+}$ binding (Fig. 4), both proteins appear to be equiv- 
alent in amount in axoplasm. Quantitative estimates, however, were made only for band 2 a (i.e., the putative $\mathrm{CaM}$ ) in Table 1 .

Our analysis indicated that squid axoplasm contained 2.5$3 \%$ of total axoplasm protein, as CaM. This value is comparable to the $0.5-1 \%$ values found in bovine brain (Table 1 ), $0.8-4.8 \%$ found in rat brain (Kakiuchi et al., 1982; Hoskins et al., 1986), and $1.8-4 \%$ found in eel electric organ (Munjaal et al., 1986). Given that squid axoplasm contains about $80 \mathrm{gm}$ protein $/ \mathrm{kg}$ axoplasm, $2.5 \%$ of this would give a CaM concentration of 2 $\mathrm{gm} / \mathrm{kg}$, or about $120 \mu \mathrm{mol} \mathrm{CaM} / \mathrm{kg}$ axoplasm. Since each mole of $\mathrm{CaM}$ is known to bind $4 \mathrm{~mol}$ of calcium ion, approximately $480 \mu \mathrm{mol}$ of $\mathrm{Ca}^{2+} / \mathrm{kg}$ of axoplasm could theoretically be bound by CaM. If, as appears to be the case in Figure 4 , the squid $M_{\mathrm{r}}$ 17,000 calcium-binding protein (band $2 \mathrm{~b}$ ) is present in comparable amounts in axoplasm, and if this protein also binds 4 $\mathrm{Ca}^{2+}$ ions, as indicated by Head et al. (1983), then the $\mathrm{Ca}^{2+}$ binding of these 2 proteins would come to $960 \mu \mathrm{mol} \mathrm{Ca}{ }^{2+} / \mathrm{kg}$ axoplasm. Adding to this the presumed $24 \mu \mathrm{mol} / \mathrm{kg}$ bound by neurofilament proteins, we estimate that the theoretical calcium-binding capacity of proteins in axoplasm is about $1 \mathrm{mmol}$ $\mathrm{Ca}^{2+} / \mathrm{kg}$ axoplasm. We have not considered the relatively small contribution of $\mathrm{CnB}$ (Table 1) or band 1 (Fig. 4), or that of band $C$ in Figure 1, which we have not yet identified. Thus, the energyindependent component of calcium buffering, discussed earlier, could easily be accounted for by axoplasm calcium-binding proteins.

What might be the functional significance of this high calciumbinding capacity in axoplasm? The identification of a number of calmodulin-binding proteins in axoplasm (e.g., fodrin, calcineurin, and $\mathrm{Ca}^{2+} / \mathrm{CaM}$ protein kinase II in Fig. 6) suggests that $\mathrm{Ca}^{2+} / \mathrm{CaM}$-regulated processes are occurring in axoplasm, although their specific biological functions in the squid axons are at present unclear. It could be that the $\mathrm{Ca}^{2+}$-binding proteins in axoplasm are primarily there to act as powerful $\mathrm{Ca}^{2+}$ buffers. This could provide a fail-safe mechanism for preventing the accidental activation of the calcium-dependent protease (calpain), which would be a devastating event for axonal structure (Pant et al., 1982; Eagles et al., 1988), or could be the basis for the diffusional barrier for calcium in neuronal cytoplasm often invoked by physiologists (Augustine et al., 1988); Gamble and Koch, 1987; McBurney and Neering, 1987) as one explanation of its highly localized intracellular action.

Note added in proof: In a recent paper (Lefebvre and Mushynski, 1987), describing different methods, high- and low-affinity bindings of calcium to neurofilament proteins were found. Dephosphorylation caused a reduction of low-affinity binding sites, and increases in the number and binding constant of high-affinity sites.

\section{References}

Abercrombie, R. F., K. Gammeltoft, J. Jackson, and L. Young (1986) An intracellular calcium binding site on neurofilament proteins of Myxicola giant axon. J. Gen. Physiol. 88: 9a.

Alema, S., P. Calissano, G. Rusca, and A. Guiditta (1973) Identification of a calcium-binding brain specific protein in the axoplasm of squid axons. J. Neurochem. 20: 681-689.

Augustine, G. J., M. P. Charlton, and S. J. Smith (1987) Calcium action in synaptic transmitter release. Annu. Rev. Neurosci. 10: 633693.

Baker, P. F. (1986) Strategies for calcium coupling in neurons. In Ion Channels in Neural Membranes, J. M. Ritchie, R. D. Keynes, and L. Bolis, eds., pp. 177-192, Liss, New York.
Baker, P. F., and R. Dipolo (1984) Axonal calcium and magnesium homeostasis. Curr. Top. Membr. Transport 22: 195-247.

Baker, P. F., and W. W. Schlaepfer (1975) Calcium uptake by axoplasm extruded from giant axons of Loligo. J. Physiol. (Lond.) 249: 37P.

Baker, P. F., and W. W. Schlaepfer (1978) Uptake and binding of calcium by axoplasm isolated from giant axons of Loligo and Myxicola. J. Physiol. (Lond.) 276: 103-125.

Bass, M., H. C. Pant, H. Gainer, and T. R. Soderling (1987) Calcium/ calmodulin dependent protein kinase II in squid synaptosomes. J. Neurochem. 49: 1116-1123.

Baumgold, J., S. Terakawa, K. Iwasa, and H. Gainer (1981) Membrane-associated cytoskeletal proteins in squid giant axons. J. Neurochem. 36: 759-764.

Blaustein, M. P., R. W. Ratzlaff, and E. S. Schweitzer (1980) Control of intracellular calcium in presynaptic nerve terminals. Fed. Proc. 39 . 2790-2795.

Brinley, F. J. (1978) Calcium buffering in squid axons. Annu. Rev. Biophys. Bioeng. 7: 363-392.

Carden, M. J., W. W. Schlaepfer, and V. M. Y. Lee (1985) The structure, biochemical properties, and immunogeneity of neurofilament peripheral regions are determined by phosphorylation state. J. Biol. Chem. 260: 9805-9817.

Carlin, R. K., D. J. Grab, and P. Siekevitz (1981) Function of calmodulin in postsynaptic vesicles. III. Calmodulin-binding proteins of the postsynaptic density. J. Cell Biol. 89: 449-455.

Cohen, R. S., H. C. Pant, S. House, and H. Gainer (1987) Biochemical and immunocytochemical characterization and distribution of phosphorylated and nonphosphorylated subunits of neurofilaments in squid giant axon and stellate ganglion. J. Neurosci. 7: 2056-2074.

Conner, J. A. (1986) Digital imaging of free calcium changes and of spatial gradients in growing processes in single, mammalian central nervous system cells. Proc. Natl. Acad. Sci. USA 83: 6179-6183.

DiPolo, R., and L. A. Beauge (1983) The calcium pump and sodiumcalcium exchange in squid axons. Annu. Rev. Physiol. 45: 313-324.

Eagles, P. A. M., H. C. Pant, and H. Gainer (1988) Neurofilaments. In Intermediate Filaments, P. M. Steinert and R. D. Goldman, eds., Plenum, New York.

Evered, D., and J. Whelan (eds.) (1986) Calcium and the Cell (Ciba Foundation Symposium 122), Wiley, Chichester, UK.

Gamble, E. and C. Koch (1987) The dynamics of free calcium in dendritic spines in response to repetitive synaptic input. Science 232 : 1311-1315.

Glenney, J. R., Jr., and K. Weber (1980) Calmodulin binding proteins of the microfilaments present in isolated brush-borders and microvilli of intestinal epithelial cells. J. Biol. Chem. 255: 10551-10554.

Harary, H. G., and J. E. Brown (1984) Spatially nonuniform changes in intracellular calcium ion concentrations. Science 224: 292-294.

Head, J. F., and B. Kaminer (1980) Calmodulin from the axoplasm of the squid. Biol. Bull. 159:485.

Head, J. F., S. Speilberg, and B. Kaminer (1983) Two low-molecularweight $\mathrm{Ca}^{2+}$-binding proteins isolated from squid optic lobe by phenothiazine-Sepharose affinity chromatography. Biochem. J. 209: 797802 .

Henkart, M. (1980) Identification and function of intracellular calcium stores in axons and cell bodies of neurons. Fed. Proc. 39: 2783-2789.

Hoskins, B., K. C. Burton, D. D. Liu, A. B. Porter, and I. K. Ho (1986) Regional and subcellular calmodulin content of rat brain. J. Neurochem. 46: 303-304.

Hubbard, M. J., and C. B. Klee (1987) Calmodulin binding by calcineurin: Ligand-induced renaturation of protein immobilized on nitrocellulose. J. Biol. Chem. 262: 15062-15070.

Iwasa, F., and K. Ishiguro (1986) Calmodulin-bonding protein $(55 \mathrm{~K}$ and $17 \mathrm{~K}$ ) of sea urchin eggs has a $\mathrm{Ca}^{2+}$ and calmodulin-dependent phosphoprotein phosphatase activity. J. Biochem. (Tokyo) 99: 13531358.

Kakiuchi, S., S. Yasuda, R. Yamazaki, Y. Teshima, R. Kanda, R. Kakiuchi, and K. Sobue (1982) Quantitative determination of calmodulin in the supernatant and particulate fractions of mammalian tissues. J. Biochem. (Tokyo) 92: 1014-1048.

Klee, C. B., and T. C. Vanaman (1982) Calmodulin. Adv. Protein Chem. 35: 213-321.

Klee, C. B., M. H. Krinks, A. S. Manalan, P. Cohen, and A. A. Stewart (1983) Isolation and characterization of bovine brain calcineurin: A calmodulin-stimulated protein phosphatase. Methods Enzymol. 102: 227-244. 
Kretsinger, R. H. (1976) Calcium-binding proteins. Annu. Rev. Biochem. 45: 239-266.

Kretsinger, R. H. (1982) Structure and evolution of calcium-modulated proteins. CRC Crit. Rev. Biochem. 8: 118-174.

Laemmli, U. K. (1970) Cleavage of structural proteins during the assembly of the head of bacteriophage T4. Nature 227:680 685.

Lasek, R. J. (1974) Biochemistry of the squid axon. In A Guide to Laboratory Use of the Squid, Loligo pealei, J. M. Arnold, ed., pp. 6974, Marine Biological Laboratory, Woods Hole, MA

Lefebvre, S., and W. E. Mushynski (1987) Calcium binding to untreated and dephosphorylated porcine neurofilaments. Biochem. Biophys. Res. Comm. 145: 1006-1011.

Lowry, O. H., N. J. Rosebrough, A. L. Farr, and R. J. Randall (1951) Protein measurement with the folin phenol reagent. J. Biol. Chem. 193: 265-275.

Manalan, A. S., and C. B. Klee (1984) Calmodulin. Adv. Cyclic Nucleotide Protein Phosphorylation Res. 18: 227-277.

Martinosi, A. N. (1983) The regulation of cytyoplasmic $\mathrm{Ca}^{2+}$ concentration in muscle and non-muscle cells. Muscle Non-Muscle Motil. 1: $223-356$

Maruyama, K., T. Mikawa, and S. Ebashi (1984) Detection of calcium binding proteins by ${ }^{45} \mathrm{Ca}$ autoradiography on nitrocellulose membrane after sodium dodecyl sulfate gel electrophoresis. J. Biochem. 95: 511 519.

McBurney, R. N., and I. R. Neering (1987) Neuronal calcium homeostasis. Trends Neurosci. 10: 164-169.

McCleskey, E. W., A. P. Fox, D. Feldman, and R. W. Tsien (1986) Different types of calcium channels. J. Exp. Biol. 124: 177-190.

Miller, R. J. (1987) Multiple calcium channels and neuronal function. Science 235: 46-52.

Morris, J. R., and R. J. Lasek (1984) Monomer-polymer equilibria in the axon: Direct measurement of tubulin and actin as polymer and monomer in axoplasm. J. Cell Biol. 98: 2064-2076.

Munjaal, R. P., C. G. Connor, R. Turner, and J. R. Dedman (1986) Eel electric organ: Hyperexpressing calmodulin systcm. Mol. Cell. Biol. 6: 950-954.
Pant, H. C., G. Schecket, H. Gainer, and R. J. Lasek (1978) Neurofilament protein is phosphorylated in the squid giant axon. J. Cell Biol. 78: R23-R27.

Pant, H. C., P. E. Gallant, R. Gould, and H. Gainer (1982) Distribution of calcium activated protease (CAP) activity and endogenous substrates in the squid nervous system. J. Neurosci. 2: 1578-1587.

Pant, H. C., P. E. Gallant, and H. Gainer (1986) Characterization of a cyclic nucleotide- and calcium-independent neurofilament protein kinase activity in axoplasm from the squid giant axon. J. Biol. Chem. 261: 2968-2977.

Rasmussen, H. (1981) Calcium and cAMP as Synarchic Messengers, Wiley, New York.

Rose, B., and W. R. Loewenstein (1975) Calcium ion distribution in cytoplasm visualized by aequorin: Diffusion in cytosol restricted by energized sequestering. Science 190: 1204-1206.

Rubin, R. P. (1974) Calcium and the Secretory Process, Plenum, New York.

Sawyer, D. W., J. A. Sullivan, and G. L. Mandell (1985) Intracellular free calcium localization in neutrophils during phagocytosis. Science 230: 663-666.

Schlacpfcr, W. W. (1974) Calcium-induced degeneration of axoplasm in isolated segments of rat peripheral nerve. Brain Res. 69:203-215.

Somlyo, A. P., M. Bond, and A. V. Somlyo (1985) Calcium content of mitochondria and endoplasmic reticulum in liver frozen rapidly in vivo. Nature 314: 622-625.

Towbin, H. T., T. Stehelin, and J. Gordon (1979) A procedure for the electrophoretic transfer of proteins from polyacrylamide gels to nitrocellulose sheets and some applications. Proc. Natl. Acad. Sci. USA 76: 4350-4354.

Wier, W. G., M. B. Cannell, J. R. Berlin, E. Marban, and W. J. Lederer (1987) Cellular and subcellular heterogeneity of $\left[\mathrm{Ca}^{2+}\right]$ : In single heart cells revealed by Fura-2. Science 235: 325-328.

Williams, D. A., K. E. Fogarty, R. Y. Tsien, and L. F. Fay (1985) Calcium gradients in single smooth muscle cells revealed by the digital imaging microscope using Fura-2. Nature 318: 558-561. 